\title{
The Eight-Consciousness Model of Ethical Decision Making
}

\author{
Jen-Sheng Liao ${ }^{a^{*}}$, Charles S. Chien ${ }^{b}$ \\ a Ph.D. Program of Business, College of Business, Feng-Chia University, Taichung City, Taiwan 40724. \\ b Associate Dean, College of Business, Feng-Chia University, Taichung City, Taiwan 40724. E-mail: scchien@fcuoa.fcu.edu.tw \\ *Corresponding author's email address: jenshengliao@yahoo.com.tw
}

\begin{tabular}{|c|c|}
\hline A R T I C L E & A B S T R A C T \\
\hline \multirow{4}{*}{$\begin{array}{l}\text { Received: } 02-10-2017 \\
\text { Accepted: } 14-10-2017 \\
\text { Available online: } 16-10-2017\end{array}$} & This article explores a model of Vijñānavāda, generally known as the eight \\
\hline & consciousnesses, which relates to understanding consciousness itself from the \\
\hline & Vijñānavāda perspective. The model is mainly based on the description in the "Verses \\
\hline & $\begin{array}{l}\text { Delineating the Eight Consciousnesses" ("Verses").According to the eight-consciousness } \\
\text { model, our entire consciousness involves the eye, ear, nose, tongue, body, mental }\end{array}$ \\
\hline \multirow{4}{*}{$\begin{array}{l}\text { Keywords: } \\
\text { Ethical decision; } \\
\text { Eight consciousness; } \\
\text { Vijñānavāda, manas. }\end{array}$} & consciousness, the manas, and the ālayavijñāna. These components are presented as \\
\hline & beginning with the single mind through the increasing complexity of the process of \\
\hline & consciousness. In this article, this model is examined as a potential theoretical resource \\
\hline & $\begin{array}{l}\text { that can guide insight, knowledge, and enlightenment. Herein, it is described how the } \\
\text { eight-consciousness model can increase our understanding of ethical decision making } \\
\text { and develop a perspective that can facilitate enlightenment. This paper does not }\end{array}$ \\
\hline \multirow{2}{*}{$\begin{array}{l}\text { JEL Classification: } \\
\text { A13; D82. }\end{array}$} & conduct an in-depth review of the doctrine of Vijñannavāda. However, when considering \\
\hline & $\begin{array}{l}\text { the actions and intentions that occur in the mind, this investigation demonstrates the } \\
\text { transformation of consciousness into wisdom. }\end{array}$ \\
\hline
\end{tabular}

(C) 2017 The Authors. This is an open access article under the terms of the Creative Commons Attribution License 4.0, which allows use, distribution and reproduction in any medium, provided the original work is properly cited.

\section{Introduction}

\subsection{Background}

The ethical decision-making (EDM) process has been widely discussed by practitioners through a variety of approaches, and its dominance as a rationalist and a non-rationalist approach of intuitionism is growing (Haidt, 2001; Jones, 1991; Rest, 1986; Sonenshein, 2007). However, such theoretical and empirical studies are presently being conducted without an understanding of or interest in metaphysics and philosophy (Williams \& Gantt, 2009). The absence of a well-developed theoretical methodological foundation has given rise to various challenges within this field, such as the lack of a standardized research method that can present consistent findings (Pan \& Spark, 2012) and the inability to account for complex neurocognitive-affective variables (Schwartz, 2016).

Vijñānavāda is a mainstream concept of Chinese Mahāyāna Buddhism (Kaag, 2012). It is not a tradition solely dedicated to exploring the ideation (vijñaptimātra) of the universe (Nedu, 2015); to achieve enlightenment, it also focuses on analyzing and describing how human experience is constructed by the mind (Waldron, 2008). According to the Vijñānavāda tradition, conceptual knowledge appears at the level of mental consciousness (the sixth consciousness), which, in turn, is determined by the manas (the seventh consciousness). Because the manas are responsible for the appearance of errors perpetrated by the individual 
self, such errors will also characterize any form of conceptual knowledge that appears at the level of mental consciousness. Thus, the theory accounting for the conditioning of decision making finds that it stems from two factors. On the one hand, decision making is conditioned by the manas of individuality; on the other hand, it is conditioned by the seeds existing within the ālayavijñana (the eighth consciousness) (Nedu, 2015).

\subsection{Objective}

Current EDM studies have rarely explored psychological and neuroscientific perspectives of the Vijñānavāda School. To determine what light can be shed on modern theories of EDM, and because much of the understanding and practice of ethics in psychology arose from dialogue with Buddhist traditions (Finnigan, 2011; Harvey 2000), this article carefully explores the ancient model found in the Vijñanavāda tradition, known as the eight consciousnesses, and as described in "Verses Delineating the Eight Consciousnesses." These verses, written by Tripitaka Master Xuanzang (玄藏, AD 596-664), hold a summary of the doctrine contained in Xuanzang's most celebrated work, Treatise on Consciousness-Only. Vijñānavāda is a very dense, vast, and complex subject that has undergone a number of striking developments. This paper does not treat the existence of these notions as a battle between different schools of thought in Buddhism; rather, the paper only discusses the main, basic accounts to bridge the gap between moral judgment and moral action.

\subsection{Contribution to the field}

This eight-consciousness model is explored here as a potential theoretical resource that can guide insight, knowledge, and enlightenment. This article shows how the eight-consciousness model can increase our understanding of EDM and develop a perspective that can facilitate enlightenment. When due consideration is made for the actions and intentions that occur in the mind, it is clear that these investigations represent the transformation of consciousness into wisdom. Practical applications of the model are also presented.

\section{Literature}

\subsection{Ethic types and moral judgment}

Several types of ethics have been defended by philosophers and theologians. These include utilitarian ethics, virtue ethics, and value ethics (Barbour, 2014). Utilitarian ethics involves judging decisions entirely by their consequences, not by intentions, motives, rights, or duties. A criterion of utilitarian ethics is to maximize the total good, which is to make a decision that provides "the greatest good to the greatest number." Virtue ethics is influential in considering ethics within a family, church, synagogue, or community. Character education occurs within particular religious or secular traditions, and virtue ethics relies upon decisions based on character. Value ethics is a broad goal sought in individual and social life. Values can be defended on either religious or secular grounds and then applied as shared criteria in policy choices (Barbour, 1993; 2014).

Moral judgment is defined as the evaluation of events, persons, or acts, according to the laws, obligatory virtues, and cultural norms that constitute the standards of the larger community (Haidt, 2001; Jones, 1991). Therefore, if judgment is against or violates laws, virtues, or cultural norms, this would be an immoral judgment. The paper will use the terms "ethical" and "moral" and "moral judgment" and "moral decision making" interchangeably.

\subsection{Review of empirical research on ethical decision making}

There have been three general moral-judgment models used in prior research: (a) rationalist-based; (b) nonrationalist-based; and (c) an integrated approach.

\section{(a) Rationalist-based}

There has been experimental work on EDM, such as Kohlberg's (1973) work on cognitive moral development and Rest and John's work on the four distinct process components and moral intensity (see, e.g., John, 1991; Rest, 1986). The person-situation integrationist model has also received attention (Trevino, 1986).

Rest's (1986) four processes include moral awareness, judgment, intent, and behavior. Jones (1991) adopts Rest's (1986) four-stage model and extends it by proposing that the nature of a moral issue, also called the moral intensity, influences all stages of the moral decision-making process. Recently, research efforts focus on the relationship between moral judgment (i.e., moral or unethical judgments), moral intention (i.e., the intention to do what is moral or what is unethical), and moral actions (i.e., moral or immoral behavior) (Dedeke, 2015).

\section{(b) Nonrationalist-based}

After decades of rationalist dominance under the auspices of a cognitive paradigm (Kohlberg, 1971), moral psychology has shifted toward emotion and intuition (Haidt, 2001). Haidt (2001) proposes a descriptive model of moral decision making (i.e., a model that describes how people actually make decisions), in contrast to normative decision making. He asserts that the determination of what is right or wrong is driven largely by 
unconscious intuitions rather than cognitive deliberative ones.

\section{(c) Integrated approach}

The nature of intuition has been explored quite extensively as part of a dual-process theory. According to the dual-process model, decision making involves two stages wherein there is concurrent interaction between intuition (impulse) and reason (reflection) (Reynolds, 2006) or between emotion and reason, leading to moral judgment (Greene et al., 2001).

Greene et al. (2001) proposes the dual-process theory (DPT) of moral judgment. This model is similar to the social intuition approach (Haidt, 2001) in that it assigns the dominant role in decision making to automatic intuitive responses (Dedeke, 2015). In other words, emotions/intuitions have primacy. DTP and SIM assert that automatic emotions largely drive intuitions, which is a proposition that seems to conflict with the results that we have from other fields, such as the realm of social cognition. However, they did not clearly address what kinds of emotions will affect moral judgment.

In the dual-process model, there are two distinct types of cognitive processes. Type 1 and Type 2 are generally opposites: Type 1 is fast and intuitive and Type 2 is slow and deliberative. Evans and Stanovich (2013) separate these attributes into two primary differences. One is their difference in working memory. In particular, Type 1 processes do not require working memory, whereas Type 2 processes do. The other primary difference is that Type 1 processes are largely autonomous, whereas Type 2 processes often require mental simulation (Evans \& Stanovich, 2013, p. 225). Which of the two systems is responsible for moral judgment? Rationalist models seem to suggest that moral judgment is based on deliberate reflection and the careful weighing of reasons, but non-rationalist models suggest moral judgment is based on uncontrolled, emotionally-charged states of intuitive (dis)approval. However, neither side has robust research-based support.

\subsection{Moral personhood}

One type of behavior ethics is moving towards theories of moral development that espouse models of moral personhood to close the gap between moral judgment and moral action (Ellertson et al., 2016). The gap refers to the incongruity between an individual's EDM and the actions that follow moral judgment (Ellertson et al., 2016). Moral personhood implies an owner with the full scope of agentic moral psychological processes who can entail both sophisticated moral judgments and well-developed moral personalities (Frimer \& Walker, 2008).

To fill the gap, Kohlberg (1971) hold the view that moral reasoning is the basis for ethical behavior and set forth six identifiable developmental stages; however, he does not examine how individuals relate to their own conceptions of what is good and what is right (Kohlberg et al. 1983). Blasi (1995) claim that the moral self and the moral identity are the keys to bridging this gap, but he does not explain how such universal principles are incorporated into the self to produce a moral identity.

Haidt (2001) speaks of moral intuitions as being capable of producing moral behavior, but he has no plausible explanation for why a person may not respond consistently with paleo-moral assessments. Ellertson et al. (2016) argue that intuition is just moral behavior because morality should be metaphysically fundamental. But where does this metaphysical moral intuition come from and how could we induce it?

\section{Understanding the eight consciousnesses}

\subsection{The first five consciousnesses}

The first five consciousnesses are the perceptual ones. They comprise the visual, auditory, olfactory, gustatory, and tactile senses. These senses arise from the perceived division of the eighth consciousness. The first five consciousnesses work in conjunction with the sixth, which processes their input to construct a mental picture of reality (Zim, 1995).

There are five perception organs (eyes, ears, nose, tongue, and body), which are the basis or support for the activities of the first five consciousnesses. Each organ has two aspects. One is the physical organ and the other is its neural pathways (Harvey, 2013).

The Verses state "they interact with two intermediate afflictions and eight major afflictions, and greed, anger and stupidity." Greed, anger, and stupidity are the basic afflictions. The two intermediate afflictions are "lack of shame" and "lack of remorse." The eight major afflictions are restlessness, torpor, lack of faith, laziness, laxness, scatteredness, distraction, and improper knowledge.

\subsection{The sixth consciousness}

Cognition and perception take place in the sixth consciousness (the mental consciousness). Mental consciousness distinguishes all incoming data. Because the first five consciousnesses always arise together with mental consciousness, mental consciousness and all of the sense data are fed into the seventh consciousness (manas) (Clark, 2008). The character or nature of these six consciousnesses can be good, evil, or neutral (Tripitaka Master Xuanzang, 1998).

On mental consciousness, it is stated in the Verses, "Whenever it is wholesome or unwholesome, they 
make distinctions and accompany it. The basic and subsidiary afflictions together with faith and other wholesome dharmas always arise jointly with the sixth consciousness." The major function of mental consciousness is to make distinctions, such as between good and evil or between long and short. According to Vasubandhu, the basic afflictions are greed, anger, stupidity, arrogance, doubt, and improper views. Because these basic afflictions always come together, mental consciousness colors the incoming sense data and interprets it through the senses (Clark, 2011).

\subsection{The seventh consciousness}

The seventh consciousness (manas) coordinates the thoughts and information received from the six consciousnesses and is capable of reflecting, considering, and making judgments (Clark, 2011). It is important and critical that the seventh consciousness obscures a person's true nature with the ego concept, "I." This ego is not a real entity but only a perishable element of the equally perishable act of cognition (Tola \& Dragonetti, 2005). It represents a constant process of selecting what is best for the self (Clark, 2011). Buddhists see the ego as the problem or obstacle in the path to enlightenment. Thus, the seventh consciousness is also known as the defiling/transmitter consciousness because of the illusions it promotes. It defiles the first six consciousnesses by obscuring them with its concept of self, and it also defiles the eighth consciousness by attributing to it characteristics of a real self that exists in space and time (Zim, 1995).

The Verses state, "The eight derivative afflictions, the five universal interactions, the judgment of the particular states, greed, anger, doubt, and improper views all interact and accord with it .... It continuously focuses its mental activity on inquiry which results in the characteristic that is self." The eight derivative afflictions are "lack of faith, laziness, laxness, torpor, restlessness, distraction, improper knowledge, and scatteredness." Greed, anger, doubt, and improper views are four of the six basic afflictions. These eight derivative afflictions and four basic afflictions always interact with the manas. Its main function is to make judgments, which involves decision making based wholly on worldly knowledge, which is defiled by the self (Tripitaka Master Xuanzang, 1998). At the level of the manas, the delusion of $I$ arises, because this reflects the illusion that there is someone inside who is in charge, making decisions, acting on my preferences, and consciously pursuing my choices(Clark, 2011).

\subsection{The eighth consciousness}

The eighth consciousness (älayavijñana) is the storehouse consciousness that is the basis of the seven other aspects of mind. The eighth consciousness is known as the repository of impressions because from it arises from all of our ideas of self, ego, and their respective functions in the external world. The eighth consciousness is beyond the dualisms of subject and object or existence and non-existence (Tripitaka Master Xuanzang AD 596-664), and, thus, it has no purposive activity and is unaware of objects. Because it does not make distinctions and is neither good nor bad, the eighth consciousness is said to have a state of equanimity. The eighth consciousness is the karmic storehouse that contains the seeds generated by our unenlightened actions. Although it does not create karma, the alaya functions as the subject of retribution for past intended deeds. Among the great flood of seeds in the allayavijñāna, these impregnating seeds are the especially favorable potentials of wisdom in the stream of dharmas. These seeds form clusters that augment those already in our dharma stream and produce insight. The impregnating seeds are called the seeds of the dharmakaya, the true body of the Buddha (Clark, 2011). Table 01 summarizes the eight consciousnesses and their cognition.

Table 1: Eight consciousnesses' framework

\begin{tabular}{|c|c|c|c|}
\hline & Consciousness & Cognitive & Physical Form \\
\hline The first five & Eye Consciousness & Eyes & Sight \\
\hline \multirow[t]{4}{*}{ consciousnesses } & Ear Consciousness & Ears & Sound \\
\hline & Nose Consciousness & Nose & Smell \\
\hline & Tongue Consciousness & Tongue & Taste \\
\hline & Body Consciousness & Body & Feeling \\
\hline Sixth consciousness & The Mental Consciousness & Mind & Thought \\
\hline $\begin{array}{l}\text { Seventh } \\
\text { consciousness }\end{array}$ & Manas & Mind & Self-grasping \\
\hline Eighth consciousness & ālāya-vijñāna & Mind & Memory \\
\hline
\end{tabular}

\section{Comparison of the eight-consciousness model and current EDM}

\subsection{The eight-consciousness model}

The eight-consciousness model (see Figure 01) of Vijñannavāda describes the circle of the consciousness process. This model has been described as a useful resource that can give direction to the enlightenment of the mind (Nedu, 2015). 


\subsubsection{Input processes: From the first five to the eighth consciousness}

The first five consciousnesses, those of the eye, ear, nose, tongue, and body, are posited on the basis of valid straightforward cognition solely by means of faculties of bodily sense (Zim, 1995). On the other hand, the sixth consciousness (mental consciousness) distinguishes all incoming data using advanced analysis, induction, and other mental operations, based on the mental objects reflected by the states of the five sense objects. Because the five consciousnesses always arise together with the mental consciousness, the mental consciousness is fed into the seventh consciousness (manas) together with all of its sense data (Clark, 2008).

The eighth consciousness is the origin of all dharmas; as it is non-impeded and morally neutral, it stores all good, bad, and neutral karmic seeds. As it does not perceive or differentiate the states of the six objects, it functions as the substance that receives karma of each sentient being (Fan \& Chou, 2016).

Among the eight consciousnesses, the sixth is best at discerning because it possesses the mental function of wisdom, and the manas function of wisdom is the worst.

\subsubsection{Output processes: From the eighth to the first five consciousnesses}

The seventh consciousness is constantly evaluating, discriminating, and making judgments while clinging to the attributes of the eighth consciousness as its inner self. Then, conceptual knowledge and action-direction appear at the sixth consciousness, which is determined by the seventh consciousness. Finally, physical action follows the demands of the mental consciousness.

\subsubsection{Karma and dharmas}

Karma. Karma is the result of our intentional actions. The consequences of these actions remain as seeds planted in the eighth consciousness. These seeds germinate over time and generate more seeds. The karmic process has three stages: 1 ) becoming deluded in the sixth consciousness, where actions lead to activity and therefore karma; 2) creating karma and planting seeds in the eighth consciousness (Figure 01): the ongoing cycle of life, death, and rebirth draws the eighth consciousness back into the six levels of existence; and 3) finally undergoing retribution as the germination of the karmic seeds (Tripitaka Master Xuanzang, 1998).

Dharmas. Dharmas are basic interdependent patterns of lived experience within the overall flux of reality. Each dharma is a mental construct with a specific process that consists of a stream of momentary events. Dharmas arise as a consequence of attachments to an illusory reality. Dharmas interact with all eight consciousnesses. According to Great Vehicle Hundred Dharmas (大乘百法明門論), there are six fundamental afflictions (e.g., greed, anger, etc.) and 20 derivative afflictions (e.g., deceit, jealousy, torpor, and lack of shame) interacting with and affecting consciousness (Zim, 1995). Afflictions can be seen as emotions. Table 02 shows each consciousness and its involved afflictions.

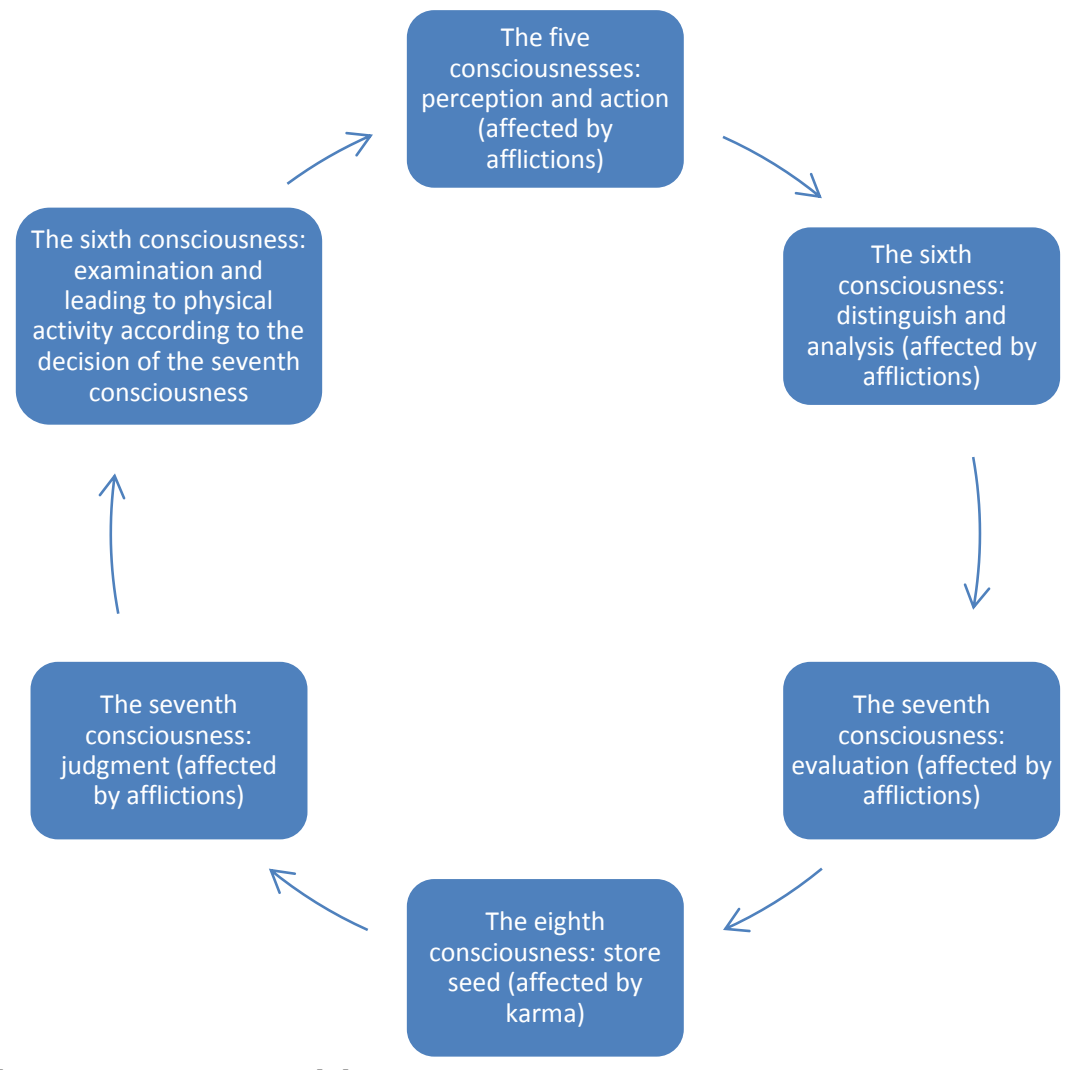

Figure 1: The eight-consciousness model 
Table 2: Afflictions in the eight consciousnesses

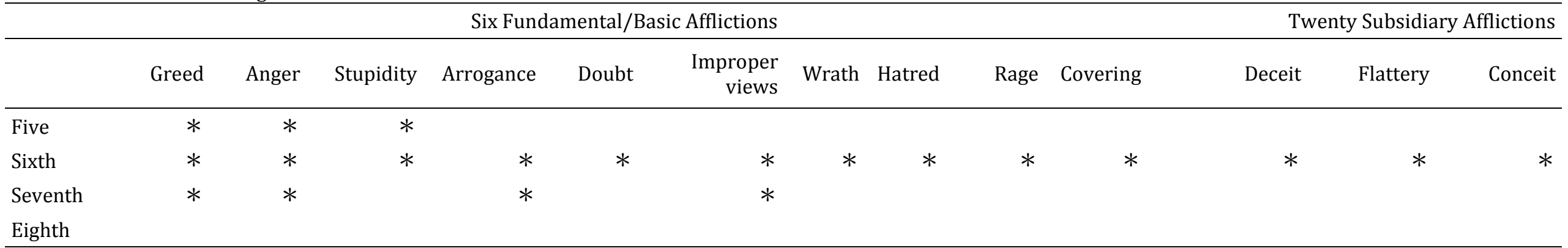

Twenty Subsidiary Afflictions

\begin{tabular}{|c|c|c|c|c|c|c|c|c|c|c|c|c|c|}
\hline & Harming & Jealousy & Stinginess & $\begin{array}{c}\text { Lack of } \\
\text { shame }\end{array}$ & $\begin{array}{r}\text { Lack of } \\
\text { remorse }\end{array}$ & Restlessness & Torpor & $\begin{array}{c}\text { Lack of } \\
\text { faith }\end{array}$ & Laziness & Laxness & Scatteredness & Distraction & $\begin{array}{l}\text { Improper } \\
\text { knowledge }\end{array}$ \\
\hline Five & & & & $*$ & $*$ & $*$ & $*$ & $*$ & $*$ & $*$ & $*$ & $*$ & * \\
\hline Sixth & $*$ & $*$ & $*$ & $*$ & $*$ & $*$ & $*$ & $*$ & $*$ & $*$ & $*$ & $*$ & * \\
\hline Seventh & & & & & & $*$ & $*$ & $*$ & $*$ & $*$ & $*$ & $*$ & * \\
\hline Eighth & & & & & & & & & & & & & \\
\hline
\end{tabular}

4.2 Two differences between current EDM and the eight consciousness Model

4.2.1 Judgment function

The differences between the methodologies used in current theories of EDM versus the eight-consciousness model can be conceptualized by examining two critical differences. One is the process of judgment and the other is the source of intuition.

As to the judgment process, current EDM theories typically emphasize the mental consciousness (sixth consciousness), which makes deliberative and analytical

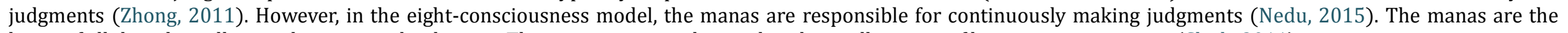
home of all thought, will, consideration, and judgment. The manas reason, plan, and evaluate all aspects of human consciousness (Clark, 2011).

\subsubsection{Intuition resource}

EDM theory considers intuition as a product of the evolutionary development of the human brain (Salvador \& Folger, 2009) or from the outside experience of

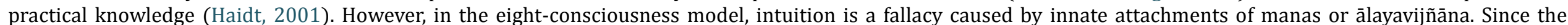

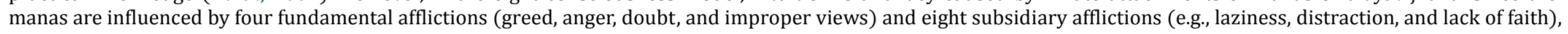

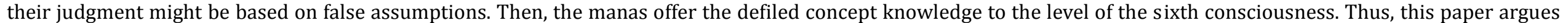
that the experiences of the operational consciousnesses are entirely subjective because they are determined by the manas. 


\section{Application of the eight-consciousness model to EDM}

\subsection{Interpreting which emotion affects intuition}

The relationship between emotions and intuition is not clear. Kahneman (2003) states that the operation of intuition is typically fast, automatic, effortless, associative, and often emotionally charged. Monin et al. (2007) argues that intuition is a behavioral guide or evaluation that directly followed an emotional experience. Dane and Pratt (2007) believe that intuitive judgments are affected and charged, and often involve emotion, suggesting that emotions either affect or cause intuition. However, they do not specify what kind of emotion affects intuition or cognition. The eight-consciousness model enables one to understand what emotion might affect intuition.

- $\quad$ At the first five consciousnesses, the emotions or vexations are greed, anger, stupidity, lack of shame, lack of remorse, restlessness, torpor, lack of faith, laziness, laxness, scatteredness, distraction, and improper knowledge.

- At the mental consciousness (the sixth consciousness), the emotions or vexations are greed, anger, stupidity, arrogance, doubt, improper view, wrath, hatred, rage, covering, deceit, flattery, conceit, harming, jealousy, stinginess, lack of shame, lack remorse, restlessness, torpor, lack of faith, laziness, laxness, scatteredness, distraction, and improper knowledge.

- At the manas process, the emotions or vexations are greed, anger, arrogance, improper views, restlessness, torpor, lack of faith, laziness, laxness, scatteredness, distraction, and improper knowledge.

\subsection{Argument for Dual Process in Moral Judgment}

The rationalist approach of EDM holds that judgment frames decisions on a rationalistic and deliberative process but suppresses the reactions of inside attention. In other words, EDM theories overly rely on mental consciousness (i.e., the sixth consciousness).

However, in the eight-consciousness model, when people face a moral dilemma and need to make a moral judgment, the all of the senses collect data and the sixth consciousness analyzes the information. Immediately, the seventh consciousness deals with all the imported data and makes a judgment. Then, the sixth consciousness acts, obeying the decision of the seventh consciousness.

Therefore, this paper argues that the dual-process model of moral judgment should be sequential. However, the process speed is too fast to be perceived sequentially. In other words, Type 1 and Type 2 cooperate almost simultaneously to shape and regulate moral judgments and decisions. In evaluating moral consequences, it is important to note that deliberative decision making (Type 2) does not always lead to negative outcomes. Rather, the outcome mostly depends on the nature of the manas, as well as its inherent and defiled afflictions.

\subsection{Enlightenment and moral personhood}

\subsubsection{Enlightenment}

As we have already explained, the Buddhist concept of mind is described as a series, succession, or current of vijñanas, such as cognitive acts, representations, ideas, and volitions. It is, therefore, necessary to take into account that these component elements of the mind can be in either their unconscious or conscious state (Tola \& Dragonetti, 2005).

Enlightenment is not achieved through conceptual understanding alone. Enlightenment requires understanding an internal transformation of consciousness. After a person's mind is enlightened and their afflictions and vexations are eliminated, the moral personhood may be achieved.

The process of the internal transformation of consciousness is three fold:

- The sixth consciousness is responsible for perception via the five modes of perception and their mental assimilation.

- The seventh consciousness, which deals with cognition and judgment, believes in a self represented by the eighth consciousness, and because the eighth contains all the seeds, the seventh takes it as its object.

- The seeds of past actions automatically ripen into the form of mental phenomena that we believe to be external events, and this is the retribution process that occurs in the eighth consciousness: the ongoing sprouting of karmic seeds confirms the reality of our senses, of our body, and the external world, which we understand via a process of five mental operations.

\subsubsection{Moral personhood}

In the seventh consciousness, because of self-grasping and afflicton, there might be no moral intuition to espouse moral personhood. Whenever people are faced with an ethical delimma, themanas always play an important role inevaluation and judgment.Becausethe manas lack moral intuition, a rationalist EDM approach seems necessary for people seeking to make an ethical decision by considering and weighing various moral standards when faced with an ethical delimma. 
In the eighth consciousness, because of the karmiceffect, moral intuition may be lackingto support moral personhood. In order to obtainperfect wisdom and undefiled consciousness, a dual-process approach may be a good choice.Each approach triggers moral intuitionby adopting a proposed method, such as praying, rational-egoism, or personal moral capacity (Vasconcelos, 2009; Woiceshyn, 2011; Schwartz, 2016).

\subsection{Implication for decision makers}

Overall, an improved account of the distinction and relationship between the eight-consciousness model and EDM would assist moral development and ethical judgment and would be particularly helpful in business and other similar contexts with complex institutional environments. First, it is important to understand that there are differences between the functions of judgment. For example, intuitive judgments are based on fast and frugal heuristics whereas rational judgments involve critical thinking as the starting point of analysis. Therefore, if we understand all of the conscious processes that can bring us to ethical judgments, we can better prepare ourselves as individuals and can better work with others to develop our collective ethical expertise.

\section{Limitation and suggestions}

\subsection{Limitation}

In order to understand the eight-consciousness model, this paper is based on the basic concept of Vijñānavāda without exploring its more complex aspects. This paper does not mention justice or how to respond to human evil. In addition, this paper does not address how decision makers, who often are not educated in Buddhism, can acquire enough knowledge of Buddhist psychology to allow them to exercise moral and spiritual leadership to diminish human evil and enhance human good.

\subsection{Suggestion}

The Buddhist five-aggregates model parallels a number of distinctions drawn in cognitive science and, therefore, serves as a useful theoretical resource for developing a cross-cultural cognitive science of consciousness. In the future, combining the eight-consciousness model and the five-aggregates model might offer a better way to understand more precisely the roles of attention and consciousness and bridge the gap between moral judgment and moral action.

\section{Conclusion}

Although the dual-process theory reflects a recent shift in EDM towards viewing intuition as a valuable object of scientific investigation (Braboszcz et al., 2010), there appears to be confusion as to how to separate the different levels of intuition. Scholars in the tradition of Vijñanavāda have divided intuition into the seventh (manas) and the eighth consciousnesses (älayavijñāna). As explained in this article, the mental consciousness obeys the decision of the manas in Buddhist practice. The manas are constantly making judgments from the perspective of a delusion of self. As described, the source of error in moral judgment seems to be the seventh consciousness (manas) through its highlighted subjective side.

There has already been a lot of research to examine the link between EDM and neuroscientific studies. However, more research is required to understand the relationship between the eight consciousnesses and ethical decision making. Certainly, the eight-consciousness model is not able to solve all problems of moral judgment. Considering that the eight-consciousness model comprehensively describes decision-making processes that take place in the mind, it not only can provide a guideline for moral judgment, but also can be helpful in instructing and teaching mindfulness.

\section{References}

Barbour, I.G. (1993). Ethics, in an Age of Technology: Gifford Lectures, 1989-1991, Vol. 2. San Francisco: Harper San Francisco.

Blasi, A. (1995). Moral understanding and the moral personality: The process of moral integration. In W. M. Kurtines \& J. L. Gewirtz (Eds.), Moral development: An introduction (pp229-253). Boston: Allyn and Bacon.

Braboszcz, C., Hahusseau, S., and Delorme, A. (2010). Meditation and Neuroscience: from basic research to clinical practice. In R. Carlstedt (Ed.), Integrative Clinical Psychology, Psychiatry and Behavioral Medicine: Perspectives, Practices and Research (pp1910-1929). New York: Springer Publishing.

Clark, J. (2011). The seeds of awakening: from a talk about the Yogachrara also known as the Vijnanavada (the school that teaches knowing) given at the Buddhist Society Summer School. Middle Way, 86, 147-161.

Clark, J. (2008). The eighth consciousness of the Yogacara: From a talk given at the Buddhist society summer school. Middle Way, 83, 67-77.

Dane, E. and Michael G. P. (2007). Exploring intuition and its role in managerial decision making. Academy of Management Review, 32, 33-54. DOI: 10.5465/AMR.2007.23463682

Dedeke, A. (2015). A cognitive-Intuition Model of Moral Judgment. Journal of Business Ethics, 126, 434-457. 
Ellertson, C. F., Ingerson, M.C. and Williams, R. N. (2016). Behavioural Ethics: A Critique and a Proposal. Journal of Business Ethics, 138 (1), 145-159. doi:10.1007/s10551-015-2628-y

Evans, J. S. and Stanovich, K. E. (2013). Dual-process theories of higher cognition: Advancing the debate. Perspectives on Psychological Science, 8, 223-241. doi:10.1177/1745691612460685.

Fan, W. H. and Chou, H. M. (2016). An analysis of the characters in Xiyou Ji through the lens of Yogacara Buddhism. Advanced Materials for Science and Engineering (ICAMSE), International Conference on IEEE. doi:10.1109/ICAMSE.2016.7840282

Finnigan, B. (2011). How Can a Buddha Come to Act? The Possibility of a Buddhist Account of Ethical Agency. Philosophy East and West, 61(1), 134-160.

Frimer, J. A. and Walker, L. J. (2008). Towards a new paradigm of moral personhood. Journal of Moral Education, 37(3), 333-356. doi: 10.1080 /03057240802227494

Greene, J. D., Sommerville, R. B., Nystrom, L. E., Darley, J. M., and Cohen, J. D. (2001). An fMRI investigation of emotional engagement in moral judgment. Science, 293, 2105-2108. doi:10.1126/science.1062872.

Haidt, J. (2001). The emotional dog and its rational tail: a social intuitionist approach to moral judgment. Psychological review, 108 (4), 814-834.

Harvey, P. (2000). An introduction to Buddhist ethics: Foundations, values and issues. Cambridge: Cambridge University Press.

Harvey, P. (2013). An introduction to Buddhism: Teaching, history and practices. Cambridge: Cambridge University Press.

Jones, T. M. (1991). Ethical decision making by individuals in organizations: An issue-contingent model. Academy of management review, 16 (2), 366-395.

Kaag, J. J. (2012). Emptiness, Selflessness, and Transcendence: William James's Reading of Chinese Buddhism. Journal of Chinese Philosophy, 39(2), 240-259. doi:10.1111/j.1540-6253.2012.01716.x

Kahneman, D. (2003). A perspective on judgment and choice: Mapping bounded rationality. American Psychologist, 58, 697-720. doi: 10.1037/0003-066X.58.9.697

Kohlberg, L. (1971). Stages of moral development. Moral education, 1, 23-92.

Kohlberg, L. (1973). The claim to moral adequacy of a highest stage of moral judgment. The Journal of Philosophy, 70 (18), 630-646.

Kohlberg, L. Charles, L. and Alexandra H. (1983). Moral stages: A current formulation and a response to critics. Switzerland : Karger

Morgan, J. (2016). Religion and dual-process cognition: a continuum of styles or distinct types? Religion, Brain \& Behavior, 6(2),112-129. doi:110.1080/ 2153599X.2014.966315

Monin, B., Pizarro, A. D. and Beer, J. S. (2007). Deciding versus reacting: Conceptions of moral judgment and the reason-affect debate. Review of General Psychology, 11, 99-111. doi: 10.1037/1089-2680.11.2.99

Nedu, O. (2015). A Non-referential and non-cognitive theory of truth, in Vijñanavada Buddhism. Revista Hiperboreea, 2 (2), 52.

Pan, Y. and Sparks, J. R. (2012). Predictors, consequence, and measurement of ethical judgments: Review and meta-analysis. Journal of business research, 65 (1), 84-91.

Rest, J. R. (1986). Moral Development: Advances in Research and Theory. New York: Praeger.

Reynolds, S. J. (2006). A neurocognitive model of the ethical decision-making process: Implications for study and practice. Journal of Applied Psychology, 91, 737-748. doi:10.1037/0021-9010.91.4.737.

Salvador, R. and Robert, G. F. (2009). Business Ethics and the Brain: Rommel Salvador and Robert G. Folger. Business Ethics Quarterly, 19 (1), 1-31.

Schwartz, M. S. (2016). Ethical decision-making theory: An integrated approach. Journal of Business Ethics, 139 (4), 755-776. doi:10.1007/S10551-015-2886-8

Sonenshein, S. (2007). The role of construction, intuition, and justification in responding to ethical issues at work: The sensemaking-intuition model. Academy of Management Review, 32 (4), 1022-1040.

Tinghög, G. et al., (2016). Intuition and moral decision-making-the effect of time pressure and cognitive load on moral judgment and altruistic behavior. Plos one, 11 (10). doi:10.1371/journal.pone.0164012

Tola, F. and Dragonetti, C. (2005). Philosophy of mind in the Yogacara Buddhist idealistic school. History of psychiatry, 16 (4), 453-465. doi:10.1177/0957154X05059213

Tripitaka Master Xuanzang (AD 596-664). (1998). Verses delineating the eight consciousnesses (Ronald. Epstein, trans in 1986). Monthly Journal of Orthodox Buddhism, 336.

Trevino, L. K., Weaver, G. R., and Reynolds,S. J. (2006). Behavioral ethics in organizations: A review. Journal of Management, 32, 951-990.

Vainio, O. P. (2016). What Does Theology Have to Do With Religion. Open Theology, 2, 106-112.

Waldron, W .S. (2008). A Buddhist theory of unconscious mind (ālayavijñāna). In K. Ramakrishna Rao; A. Paranjpe \& A. K. Dalal (Eds.). Handbook of Indian psychology (pp105-128). New York: Foundation Books.

Williams, R. and Gantt, E. (2009). Felt moral obligation and the moral judgment-moral action gap: An alternative ontological starting point. Paper presented at the 35th Conference of the Association for Moral Education, Utrecht, July. 
Woiceshyn, J. (2011). A model for ethical decision making in business: Reasoning, intuition, and rational moral principles. Journal of Business Ethics,104, 311-323. doi: 10.1007/s10551-011-0910-1.

Vasconcelos, A. F. (2009). Intuition, prayer, and managerial decision-making processes: A religion-based framework. Management Decision, 47 (6), 930-949.

Zhong, C. B. (2011). The ethical dangers of deliberative decision making. Administrative Science Quarterly, 56 (1), 1-25.

Zim, R. (1995). Basic ideas of Yogacara Buddhism.Paper Prepared for Philosophy 772 "Yogacara Buddhism". San Francisco State University. 